\title{
Research on the Role of MOOCs in Local Universities from the Perspective of Resource Dependence
}

\author{
Yuxia Qiu*, Qianyu Zhang, Wen Zhao \\ Academy of Management Science and Engineering \\ Shanxi University of Finance and Economics \\ Taiyuan 030006, China
}

\begin{abstract}
The resources of local universities in our country are relatively weak but the demand for them is relatively high. Therefore, resources have always been troubling the development of local universities. This paper studies the function and significance of the use of MOOCs in local universities from the perspective of resource dependence, especially the function of resource allocation and reengineering. Combined with the current situation of educational resource allocation in our country, this paper puts forward the development path of MOOCs in local universities based on resource dependence theory.
\end{abstract}

Keywords-resource dependence; local universities; the development path of MOOCs

\section{INTRODUCTION}

With the development of information technology, the new educational model which takes the form of 'Internet + Education" realizes the networking of educational resources [1]. The networking of educational resources refers to use information technology to achieve the re-education and teaching resources redistribution through the collection and sharing of outstanding educational resources. It's an important way to enhance the overall level of resources in China's universities [2] [3]. In the process of education resources network, some key universities exploit their resource advantages, which have played an important role for the construction of education network platform in our country. MOOCs rose in developed countries and developed globally. Its access to resources was relatively equal. The current development of MOOCs is flourishing, which is a good time for local universities to access resources and redistribute resources.

From the perspective of resource dependence theory, this paper analyzes the current situation that educational resources are distributed unevenly in our country, which can't meet the needs of the market and is not conducive to the rapid development of local universities. We can see that local universities are at a disadvantage of resources. If against the trend to utilize and develop MOOCs resources fully, narrow the power gap and reach a balance of educational resources, the quality of teaching in local universities will surely be raised. The overall teaching standards will also be improved.

\section{INTERPRETATION OF THE DEVELOPMENT OF MOOCS From the Perspective of Resource Allocation}

Resources can be divided into three categories of material, energy and information. From the perspective of resource dependence theory, which has more resources, then it has more power. Therefore, one of the effective ways to enhance the resources of local universities and narrow the gap with key universities is to obtain more educational resources, which can be borrowed (obtained from other units) or generated internally (self-created). Traditional educational resources are the most imbalanced resources of local and key universities, which are mainly controlled by material and energy resources. However, information resources can be regenerated and created in the information technology environment. Information resources are also the carrier of knowledge. If more information resources are available, it will undoubtedly be an effective way to enhance resource status for local universities. It can achieve the goal of bridging the gap between educational resources in different regions.

\section{A. MOOCs Realize the Sharing of High Quality Education Resources}

The process of adjusting the Pareto Invalid state to the Pareto Optimality, known as Pareto improvement, has the purpose of increasing the welfare of others without sacrificing the welfare of an individual, which is exactly what MOOCs do to achieve the increase of social welfare, the optimization of resource allocation profit patterns through the reallocation of existing resources. This is the most essential difference between it and school-enclosed school education, and it is also the root of its prevalence [4]. With new technologies such as cloud computing, MOOCs solved the fundamental problem which traditional education can't - the sharing of high quality education resources (traditional educational quality education resources can only be enjoyed by a few people).

\section{B. MOOCs Bridge the Gap between Educational Resources}

MOOCs form a complete learning resource based on the ubiquitous interaction between teachers, users, platforms, and the variety of course materials produced through interactions. According to the different source of resources, the information in the MOOCs platform can be divided into two categories: 
"educational content" and "user content" [5]. From the view of resource provision and content contribution, with the development of MOOCs, the main subject of resource construction, content contribution and sharing is changing from "a single subject mainly composed of teachers" to "a diversified subject mainly composed of teachers and learners", and the regional disparity in the allocation of educational information resources is narrowing.

\section{ANALYSIS OF THE CURRENT SitUATION OF}

Allocation of EduCATIONAL Resources IN CHINA

\section{A. The Supply Situation of Educational Resources}

Below we grasp the situation of the allocation of educational resources in our country through the education spending in various regions and the distribution of ordinary and key universities.

TABLE I. DISTRIBUTION OF 985, 211 AND COMMON UNIVERSITIES(2015)

\begin{tabular}{|c|c|c|c|}
\hline Category & $\begin{array}{c}\text { Number of } \\
\text { Common } \\
\text { Universities }\end{array}$ & $\begin{array}{c}\text { Number of "211 } \\
\text { Project" } \\
\text { Universities }\end{array}$ & $\begin{array}{c}\text { Number of "211 } \\
\text { Project" } \\
\text { Universities }\end{array}$ \\
\hline $\boldsymbol{B J}$ & 91 & 26 & 8 \\
\hline $\boldsymbol{S H}$ & 67 & 9 & 4 \\
\hline $\boldsymbol{G D}$ & 143 & 4 & 2 \\
\hline $\boldsymbol{J S}$ & 162 & 11 & 2 \\
\hline $\boldsymbol{Z J}$ & 105 & 1 & 0 \\
\hline $\boldsymbol{H E}$ & 118 & 1 & 0 \\
\hline $\boldsymbol{S} \boldsymbol{X}$ & 79 & 1 & 3 \\
\hline $\boldsymbol{S N}$ & 92 & 7 & 0 \\
\hline $\boldsymbol{G S}$ & 45 & 1 & \\
\hline
\end{tabular}

As can be seen from Tab.1, from 2010 to 2014, the expenditure on education in all regions is increasing, and the proportion of education expenditure in GDP is increasing basically, but the total amount of education expenditure is not enough. Generally speaking, the proportion of education expenditure gradually reached a certain standard over time. It's not difficult to find the imbalance of the distribution of educational resources in all provinces from the data. The main manifestation is that the education level in developed areas is higher than in backward areas, and that in eastern areas is higher than in central and western areas. This reflects the regional differences in education development fully.

Observing the data in Tab.2, we can see that the proportion of the key universities accounting for the total number of them is low, and the distribution of teaching resources in the province is different in the province. Among them, the key universities in Beijing $(985,211)$ accounted for $27 \%$ of the total number of schools in the city, which is the highest proportion; while some provinces only have individual key universities. The data imply the significant differences between different provinces and the uneven allocation of teaching resources.

Through the data in the above two tables, we can see the problems in the allocation of educational resources in our country clearly, including differences between different regions and different universities in the same region. There is a serious imbalance in the distribution of educational resources.

TABLE II. NUMBER OF FACULTY AND ENROLLMENT IN UNIVERSITIES (2015) (UNIT:10 THOUSAND)

\begin{tabular}{|c|c|c|c|c|c|c|c|c|}
\hline \multirow{2}{*}{ Province } & \multicolumn{6}{|c|}{ Full-time Teachers } & \multirow[b]{2}{*}{$\begin{array}{l}\text { Number of } \\
\text { Faculty }\end{array}$} & \multirow[b]{2}{*}{$\begin{array}{l}\text { Number of } \\
\text { Enrollmen }\end{array}$} \\
\hline & $\begin{array}{c}\text { Total } \\
\text { Number }\end{array}$ & Senior Teacher & $\begin{array}{c}\text { Vice- } \\
\text { Senior } \\
\text { Teacher }\end{array}$ & $\begin{array}{l}\text { Middle } \\
\text { Teacher }\end{array}$ & $\begin{array}{l}\text { Primary } \\
\text { Teacher }\end{array}$ & $\begin{array}{c}\text { None } \\
\text { Title Teacher }\end{array}$ & & \\
\hline BJ & 6.87 & 1.79 & 2.47 & 2.19 & 0.24 & 0.18 & 14.24 & 15.35 \\
\hline SH & 4.16 & 0.75 & 1.35 & 1.64 & 0.27 & 0.14 & 7.36 & 13.68 \\
\hline GD & 9.89 & 1.23 & 2.58 & 4.11 & 0.86 & 1.11 & 14.54 & 55.06 \\
\hline$J S$ & 10.72 & 1.41 & 3.60 & 4.53 & 0.84 & 0.33 & 16.23 & 44.86 \\
\hline$Z J$ & 5.95 & 0.85 & 1.83 & 2.56 & 0.36 & 0.35 & 8.87 & 26.44 \\
\hline $\boldsymbol{H E}$ & 6.94 & 0.99 & 2.09 & 2.77 & 0.77 & 0.32 & 10.28 & 32.91 \\
\hline$S X$ & 4.04 & 0.28 & 1.05 & 1.60 & 0.79 & 0.32 & 5.95 & 21.35 \\
\hline SN & 6.65 & 0.82 & 1.85 & 2.75 & 0.87 & 0.35 & 10.39 & 28.75 \\
\hline$G S$ & 2.61 & 0.31 & 0.82 & 0.99 & 0.36 & 0.14 & 3.86 & 12.43 \\
\hline
\end{tabular}

\section{B. Demand for Educational Resources in Various Regions of} China

Below we explain the current needs of educational resources around our country by analyzing the data of university faculty and admissions.

Tab. 3 shows that from the ratio between the number of enrolled students and of full-time teachers in 2015, the surge in the number of students has led to a relative shortage of teaching resources. The ratio of staff to full-time teachers in Beijing in 2015 is 1: 0.48 , indicating that there is not a small gap between the allocation of higher education in our country and the world standard allocation of 1: 1, and there is a shortage of educational resources. In the rank of full-time teachers, the share of vice-senior and middle teachers is relatively high. For example, in Beijing, vice-senior and middle teachers account for $67.8 \%$ of the total number of full-time teachers. But the real number of senior teachers is small, indicating that there is still some room for development of teachers in our country. Moreover, there are regional differences in teaching resources. The resources in the areas of Beijing, Shanghai, Guangzhou, Jiangsu and Zhejiang are more and superior to the central and western regions (Shanxi, Gansu, etc.). 
TABLE III. INNOVATION PROJECTS OF SCIENTIFIC RESEARCH AND SitUATIONS OF EXCELLENT COURSE PROJECT IN UNIVERSITIES

\begin{tabular}{|c|c|c|c|c|c|c|c|c|}
\hline \multirow[t]{2}{*}{$\begin{array}{l}\text { Names of } \\
\text { Universities }\end{array}$} & \multirow[t]{2}{*}{ Level } & \multirow[t]{2}{*}{$\begin{array}{l}\text { Academic } \\
\text { ians }\end{array}$} & \multicolumn{2}{|c|}{$\begin{array}{l}\text { Number of national } \\
\text { research projects }\end{array}$} & \multirow[t]{2}{*}{$\begin{array}{l}\text { Number of national } \\
\text { quality courses } \\
\text { (due to 2014) }\end{array}$} & \multirow[t]{2}{*}{$\begin{array}{l}\text { Number of Key } \\
\text { Laboratories }\end{array}$} & \multicolumn{2}{|c|}{$\begin{array}{l}\text { Number of National Students } \\
\text { Innovation and } \\
\text { Entrepreneurship Project }\end{array}$} \\
\hline & & & 2013 & 2014 & & & 2013 & 2014 \\
\hline Tsinghua University & $\begin{array}{l}985 \\
211\end{array}$ & 75 & 579 & 565 & 97 & 14 & 185 & 101 \\
\hline Peking University & $\begin{array}{l}985 \\
211 \\
\end{array}$ & 76 & 677 & 680 & 84 & 13 & 115 & 116 \\
\hline Fudan University & $\begin{array}{l}985 \\
211 \\
\end{array}$ & 36 & 591 & 593 & 38 & 6 & 115 & 115 \\
\hline Tongji University & $\begin{array}{l}985 \\
211 \\
\end{array}$ & 14 & 421 & 391 & 139 & 5 & 115 & 128 \\
\hline $\begin{array}{c}\text { Central University of } \\
\text { Finance and Economics }\end{array}$ & 211 & 0 & 34 & 42 & 11 & 0 & 76 & 83 \\
\hline $\begin{array}{c}\text { South China University of } \\
\text { Technology }\end{array}$ & $\begin{array}{l}985 \\
211 \\
\end{array}$ & 35 & 215 & 223 & 31 & 1 & 115 & 126 \\
\hline$X i$ 'an Jiaotong University & $\begin{array}{l}985 \\
211 \\
\end{array}$ & 24 & 376 & 379 & 62 & 5 & 109 & 133 \\
\hline $\begin{array}{c}\text { Taiyuan University of } \\
\text { Technology }\end{array}$ & 211 & 11 & 100 & 103 & 10 & 1 & 10 & 14 \\
\hline Shanxi University & & 0 & 59 & 75 & 12 & 1 & 10 & 11 \\
\hline $\begin{array}{c}\text { Shanxi University of } \\
\text { Finance and Economics }\end{array}$ & & 0 & 3 & 1 & 1 & 0 & 9 & 6 \\
\hline
\end{tabular}

\section{The Dependence of Educational Resources}

Through the above analysis, we know that there is a serious regional distribution of educational resources now in China, and some regions have greater demand for educational resources. Below we analyze the current situation of dependence on education resources through the data of some university network sharing platform. Tab.4 is part of China's universities research projects and excellent course project situations, we can see that the project of sharing courses is more in key universities, while fewer in common universities. At present, a key education network has been formed. Common universities have dependence on educational resources. In addition, the MOOCs platform in China has begun to take shape under the guidance of some key universities. The subject types also cover all aspects of university learning, which enriches the online resources. The rich teaching resources owned by key universities have resulted in a pattern of centered on them and also increased the dependence of local universities on them.

\section{MOOCs Operating Mode AND Resource Allocation CAPABILITIES}

\section{A. Universities Develop Their Own MOOCs Platform}

Under the condition that universities have sufficient resources, they can choose to develop their own resources, invest the corresponding personnel and technology and create their own MOOCs platform. In this way not only enriched the MOOCs system type, reducing the repetition rate of course, but also increased the output of college resources [6].

Local universities select distinctive and obvious industrialized high-quality courses according to the local economy, industrial structure and the type of their own schools.
They create, apply and popularize these courses according to the requirements and standards of MOOCs. The allocation of resources in this mode is a process by which local universities match "selected" courses with the existing curriculum system in schools and the demand for teaching development. It's also a necessary part of making reasonable allocation of manpower, material and financial resources in schools. Especially, it can make overall arrangements for the input of teachers and teaching funds so as to obtain the best benefits at a minimum cost. In this process, the input of education in human, material, information, time and financial resources have all reached a considerable degree of equilibrium. The basis of teaching innovation is teachers, who are the primary consideration of human factors. Schools encourages outstanding teachers and teachers who are keen on improvement to participate in MOOCs construction and application so as to find out and train a batch of teachers who can adapt to the new teaching mode as soon as possible to implement the school's "MOOCs course". Second, schools need to consider the cost of inputs, that is, financial resources. Such a budget generally based on the "choice" of course credits, teaching and research project investment, infrastructure and other aspects of cost allocation. It is supported by earmarked funds from school-related business funding. In the balance of information resources, the output of educational information has also been fully realized, so that valuable resources can be utilized reasonably.

\section{B. Universities Join the Well-known MOOCs Platform or Alliance Directly}

For schools that do not have sufficient teaching and learning resources, they usually choose to enter well-known MOOC platforms or alliances directly. In this way they can make full use of existing resources so as to achieve the goal of 
having the same level of teaching resources to first-class and second-rate universities.

According to the demand of current school development, the local universities choose some courses from the wellknown MOOCs platforms. These courses include high-demand, wide-ranging general education courses, basic courses and courses that schools have no choice but to take out [7]. The allocation of resources in this way is a kind of "introduction" mode, which can introduce higher quality resources for students at a lower cost and achieve the purpose of educational resource sharing truly. Schools using this model of human and material resources are usually scarce, that is, there is no rich teaching equipment, teachers and so on. They also achieve a balance of resource capabilities by directly targeting MOOCs platforms created by existing universities. In this way, a larger return on investment can be obtained, and human resources are released while developing information resources. Local universities can improve the quality of education resources, narrow the time gap and enhance school's reputation. Under such a development model, the expansion of scale and the abundance of resources have realized the balanced allocation of educational information resources in space and increased the fairness of access to resources.

\section{CONCLUSIONS}

From the perspective of resource dependence, this paper studies the role and significance of MOOCs development and utilization in local universities. Combined with the current situation of the distribution of educational resources in our country, this paper puts forward the development path of MOOCs in local universities based on the theory of resource dependence. The main conclusions are as follows:

1) At present, there is a serious shortage of educational resources in our country. Starting from the theory of resource dependence, the status of universities in the entire system is determined by the resources they own. In order to develop, local universities must improve their own resource utilization efficiency and increase the amount of resources they own.

2) The emergence and development of MOOCs is equivalent to establishing a platform for sharing educational resources, which enables the users of the platform to enjoy high-quality resources and make full use of them.

3) Information-based teaching model will lead to the redistribution of educational resources. Local universities should seize this opportunity, combine their MOOCs construction path to absorb and develop in the process of resource allocation so as to improve their own resource status.

The emergence of MOOCs is a milestone in the development of online higher education. "Waiting and see" is not feasible for local universities (or education departments). From a resource-dependent perspective, the demand for education and the disruption in supply are likely, although people are not always predicting the severity and timing of disruptions. Faced with the scale and visibility of MOOCs and the linkage of MOOCs with all existing sensitive policy issues in a swinging world of higher education, policies related to MOOCs have become an important factor influencing their future development.

Universities should explore the MOOCs construction path actively in light of their own conditions and try to integrate it with a new education system that includes many forms of education, such as traditional, continuing, online education and self-study examinations. It can promote the innovation of MOOCs-based education system and mechanism, improve the quality of teaching resource sharing, and as well achieve a balance between education scale, effectiveness and effectiveness. Finally, it will give play to the social responsibilities and advantages of universities, and promote the formation of an open educational ecological pattern oriented to the sharing of human knowledge.

\section{REFERENCES}

[1] Weihan Liu, "Research on the mechanism of constructing and sharing network education resources,” J. Modern Intelligence, 2007, vol. 12, pp.161-162.

[2] Ruiyi Hua, Jindong li and Jin Jin, "A study on the sharing of quality education resources with the opportunity of MU course,” J. Management Manager, 2015, vol. 02, pp.364-365.

[3] Sanjiu Yan and Rui Zhong, "Fair sharing and sustainable development of educational resources: MOOCs,” J. China's population resources and environment, 2015, vol.02, pp.176-178.

[4] Zhao Jia and Wenjie Zhou, "The impact of MOOCs resources on traditional higher education” J. Intelligence, 2014, vol.34, pp.270-271.

[5] Dongmei Xiao, Xiuwen wu and Fang Liu, "Deconstruction of the phenomenon of MOOCs from the perspective of educational resources allocation,” J. Library, 2015, vol.05, pp.17-21.

[6] Sen Liu and Bing Wu, "A new way to share global education resourcesMOOCs,” J. Intelligence, 2015, pp.08-203. 